\title{
LONG-TERM STABILITY CALCULATION OF RESERVOIR BANK SLOPE CONSIDERING WATER-ROCK INTERACTION
}

\author{
Liang-Peng Wan, Mei-Ling Zhou, Subin Desar
}

Preliminary communication

Early warning and forecast have always been the key points for landslide research because the disaster caused by landslide leads to enormous life and property loss. This article applies the transformed degradation results of rock to rock mass to calculate the stability and failure mode changes of landslide over time, and to guide engineering through experiment based on hydro-fluctuation belt water-rock interaction of Three Gorges Reservoir area. The results showed that until the rock mass degrades to a certain extent, the sliding zone export gets rise, the slip plane moves to surface, the back edge crack surface gets down, and the sliding mass gradually narrows down. As the ability of hydro-fluctuation belt to resist upper rock mass load reduces, the hydrofluctuation belt collapses at the first, and then causes the back edge crack resulting in huge amount of rock mass slip. The contribution of each parameter in different stratum to landslide stability is studied through sensitivity analysis. Based on this, the comprehensive strength parameter can be evaluated and calculated combined with continuous deterioration of hydro-fluctuation belt. The comprehensive strength parameter can reflect comprehensive disaster resist capacity of landslide. The research results provide a reference for actual project, and the research methods provide a new way for landslide early warning and forecast.

Keywords: comprehensive strength; deteriorating rule; failure mode; reservoir bank slope; stability analysis; water-rock interaction

\section{Proračun dugoročne stabilnosti nagiba nasipa akumulacije s obzirom na interakciju voda-stijena}

Prethodno priopćenje

Rano upozorenje i prognoza oduvijek su ključne točke u istraživanju klizišta jer katastrofa koju izaziva klizište rezultira ogromnim gubitkom života imetka. U radu se transformirani rezultati degradacije mase jedne stijene u odnosu na drugu primjenjuju u izračunu promjena stanja stabilnosti i propadanja klizišta tijekom vremena te kao vodič kroz eksperiment zasnovan na interakciji voda-stijena hidro fluktuacijskog pojasa područja akumulacije Three Gorges. Rezultati su pokazali da dok stijenska masa ne degradira do određene mjere, područje klizišta se povećava, klizna površina se kreće ka površini, spušta se napukla površina stražnjeg ruba i masa klizišta se postepeno sužava. Budući da se sposobnost hidro-fluktuacijskog pojasa da se odupre težini gornje stijenske mase smanjuje, hidro-fluktuacijski pojas se najprije urušava, a zatim dovodi do pucanja stražnjeg ruba što rezultira klizanjem velike količine stijenske mase. Doprinos stabilnosti klizišta svakog parametra u raznim slojevima proučava se analizom senzitivnosti. Na temelju toga parametar čvrstoće se može procijeniti i izračunati u kombinaciji s trajnim padom kvalitete hidro-fluktuacijskog pojasa. Parametar potpune čvrstoće može odražavati uključenu sposobnost klizišta da se odupre katastrofi. Rezultati istraživanja upućuju na postojeći projekt, a metode istraživanja predstavljaju novi način za rano upozorenje i predviđanje klizišta.

Ključne riječi: nagib nasipa akumulacije; interakcija voda-stijena; pravilo pogoršanja stanja; način kvara; analiza stabilnosti; potpuna čvrstoća

\section{Introduction}

The researches on degradation of water-rock interaction have achieved some results in recent years [1, 2]. The landslide102 in Chinese Sichuan-Tibet highway has been affected strongly by water-rock interaction in various forms, causing road blockage and casualties per annum; Xiangxi bank slope and Shaxi Temple slope groups in Three Gorges Reservoir of China are all typical degraded slope groups under water-rock interaction. The reservoir water level fluctuation in Sichuan basin red-bed region has caused a series of landslides and mudstone due to softening of sandstone. They all brought harmful influence to the reservoir operation.

At present, according to the test results of uniaxial compression, it is found that the damage characteristics of sandstone emerges a kind of conversion from brittle to ductile under cyclic drying-wetting effect [3]. M.L. Lin et al. conducted researches on mechanical property change rule of sandstone under cyclic drying-wetting effect [4]. Zhang Ming et al. [5] and LIU Xin-Rong et al. [6] did numerical simulation of bank slope stability under cyclic water-rock effect. But, it is relatively rare that the degradation rule of sandstone obtained from laboratory test was applied to predict the stability of rock mass. This paper, based on the typical slope (Muyubao bank slope) in Three Gorges Reservoir area, considers the degradation of rock mass caused by water-rock interaction, establishes a function to describe relationship between dry-wet cycle times and damage period, converts mechanical parameters of rock into rock mass, calculates the safety factor under different degree of degradation and constructs a comprehensive system of slope stability evaluation. The evaluation results of the slope were compared with the landslide safety factor under corresponding phase, then a forecasting system based on time deduction was established.

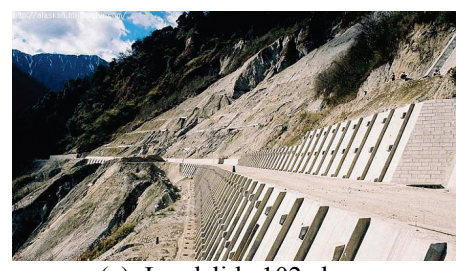

(a) Landslide 102 slope

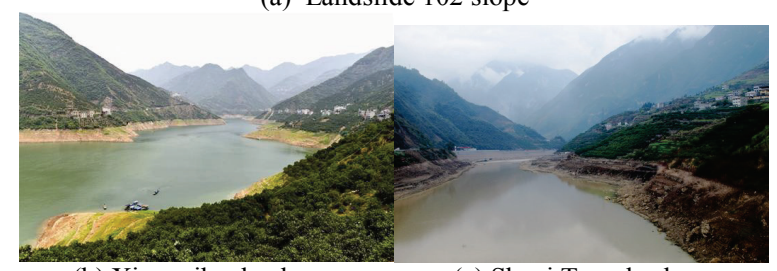

(b) Xiangxibank slope

(c) Shaxi Temple slope

Figure 1 Landslide 102 slope, Xiangxi bank slope and Shaxi Temple slope 
Three Gorges Reservoir areas is one of the rainstorm centres in China, the reservoir has accumulative rainfall greater than $25 \mathrm{~mm}$ per day which is considered as a heavy rain, and the frequency is 9 to 15 times per annum. The accumulative rainfall greater than $50 \mathrm{~mm}$ per day occurs mainly during April to September and is considered as a rainstorm with the frequency of 2 to 5 times per annum. The flood frequency is 2 to 4 times per decade. Flood mainly occurs from April to October often in the east area of the reservoir. The torrential rain causes many geological disasters related to landslide such as erosion and collapse etc.

The reservoir level drops down from January to September and increases from September to December as shown in Tab.1 [9]. The drop rate is slower than the rise rate, leading the hydro-fluctuation belt in a dry-wet circulation with rapid saturation and slow drainage, waterrock interaction is a process that water gets in and out the rock over and over again under different water pressure conditions.

Table 1 Changes of water level in three gorges reservoir annually

\begin{tabular}{|c|c|c|c|c|c|c|c|}
\hline $\begin{array}{c}\text { Month } \\
\text { value }\end{array}$ & 1 & $2 \div 3$ & 4 & 5 & $6 \div 9$ & 10 & $11 \div 12$ \\
\hline $\begin{array}{c}\text { Water } \\
\text { level } / \mathrm{m}\end{array}$ & $175 \div 170$ & $170 \div 165$ & $165 \div 160$ & 155 & 145 & $154 \div 175$ & 175 \\
\hline
\end{tabular}

Degradation effect of water on rock will cause landslide deformation, and cannot be ignored. Preliminary estimate shows that large water level fluctuation in reservoir area takes place once a year; the frequency of heavy rain and rainstorm is about 15 times per year, and every 3 years add a flood.

\section{Rock deterioration rule analysis \\ 2.1 Model of rock deterioration rule under water-rock interaction}

Sandstone is the main member in reservoir area, many scholars had conducted series of experiments on sandstone in the areas using free saturation method to make sample saturate $[6 \div 8]$. Soaking time was calculated in hours, drying process made the moisture content of samples tend to zero. Numerical fitting is applied to experimental data. In view of rock weathering, after several times $(N \rightarrow \infty)$ of water-rock interaction, cohesion turned to be zero (that is to say the rock is completely weathered to soil), internal friction angle should be very small, but not zero. Therefore, in order to reflect those two characteristics, the least squares fitting formulas are used as follows [6]:

$$
\begin{aligned}
& c=c_{0}-1,6665 \cdot \ln (N+1) . \\
& \varphi=\left(0,492 \cdot \mathrm{e}^{-0,0416 \cdot N}+0,508\right) \cdot \varphi_{0} .
\end{aligned}
$$

where $c$ is the degraded cohesive force, $c_{0}$ is the initial cohesive force; $\varphi$ is the degraded angle of internal friction, $\varphi_{0}$ is the initial angle of internal friction values, $N$ is water-rock interaction times. From the formulas, the degradation model is only applicable to sandstone which has strong parameters because the initial cohesive force should be above 1,16 to meet the requirements of degradation.
Besides, the results of the study used to reflect the effect of reservoir water on rock in hydro-fluctuation belt area are questionable because water pressure exists during the process of rock soaking. The degrading effect of water pressure on rock cannot be ignored, so, free saturation method cannot meet the requirements. To simulate the effect of water-rock interaction on rock [9], three kinds of soaking test were conducted with the handmade YRK-1 rock dissolution tester which is researched and developed by the team of author. Soaking time was calculated monthly to simulate different water levels, and mechanical tests were carried out on rock samples following the soaking test. According to the results and weathering degree, the test data were fitted in the form of Eq. (3):

$y=y_{0} \cdot\left[1-a \cdot \ln \left(1+b N^{c}\right)\right]$.

where: $y$ is a strength parameter value; $y_{0}$ is initial value of $a$ strength parameter; $a, b$ and $c$ is coefficient of degradation model that is matched; $N$ is the time of waterrock interaction

Eq. (3) is called degradation function. In rock slope, the disturbed height of hydro-fluctuation belt is in a certain depth of wading surface where tectonic stress is small. Taking confining pressure as zero, the mechanical parameters of degradation function in experiment are as Eq. (4), Eq. (5) and Eq. (6) [9] shows:

(1) Hydrostatic pressure:

$c=c_{0} \cdot\left[1-0,093 \cdot \ln \left(1+0,1953 \cdot N^{2,1045}\right)\right]$
$\varphi=\varphi_{0} \cdot\left[1-0,0221 \cdot \ln \left(1+0,7706 \cdot N^{4,1765}\right)\right.$

(2) Hydrostatic pressurized $(p=0,4 \mathrm{MPa})$

$$
\begin{aligned}
& c=c_{0} \cdot\left[1-0,1478 \cdot \ln \left(1+0,222 \cdot N^{1,6082}\right)\right], \\
& \varphi=\varphi_{0} \cdot\left[1-0,0464 \cdot \ln \left(1+0,6303 \cdot N^{2,3776}\right)\right] .
\end{aligned}
$$

(3) Hydrostatic pressurized $(p=0,8 \mathrm{MPa})$

$$
\begin{aligned}
& c=c_{0} \cdot\left[1-0,1908 \cdot \ln \left(1+0,2343 \cdot N^{1,4639}\right)\right], \\
& \varphi=\varphi_{0} \cdot\left[1-0,0499 \cdot \ln \left(1+0,7835 \cdot N^{2,2548}\right)\right] .
\end{aligned}
$$

Hydrostatic pressure can be confirmed through those three sets of fitting formula, the function of $a, b, c$ under pressurized hydrostatic can be obtained through interpolation.

It is detrimental in researching the degrading effect of water on rock as water pressure increases from top to bottom in triangular form in practice, and also the water level fluctuates between $145 \mathrm{~m}$ and $175 \mathrm{~m}$, with the amplitude of $30 \mathrm{~m}$. Thus, the biggest pressure is considered to be $0,3 \mathrm{MPa}$. The equal area method is used to simulate water pressure: $0,15 \mathrm{MPa}$ water pressure is used to simulate triangularly distributed water pressure to analyse the degrading effect of reservoir water fluctuation on rock in hydro-fluctuation belt.

The value of $a, b$ and $c$ in different hydrostatic pressure was obtained by the fitting formula to reflect the 
degradation rule of rock in different hydrostatic pressure, as water-rock interaction times increase.

While the hydrostatic pressure is $0,15 \mathrm{MPa}$, the degradation rule of rock is given by Eq. (7):

$$
\begin{aligned}
& c=c_{0} \cdot\left[1-0,1149 \cdot \ln \left(1+0,2070 \cdot N^{1,8771}\right)\right], \\
& \varphi=\varphi_{0} \cdot\left[1-0,0337 \cdot \ln \left(1+0,6836 \cdot N^{3,3055}\right)\right] .
\end{aligned}
$$

\subsection{The changes in mechanical parameters of sandstone over time}

Tab. 2 displays the total rainfall times and reservoir water fluctuation times with years increase.

Table 2 Relation between the number of water-rock interaction and

\begin{tabular}{|c|c|c|c|c|c|c|c|c|c|c|}
\hline Year value & 1 & 2 & 3 & 4 & 5 & 6 & 7 & 8 & 9 & 10 \\
\hline $\begin{array}{c}\text { Rainfall } \\
\text { times }\end{array}$ & 16 & 32 & 49 & 65 & 86 & 98 & 114 & 130 & 146 & 163 \\
\hline $\begin{array}{c}\text { Fluctuation } \\
\text { times of } \\
\text { reservoir } \\
\text { water }\end{array}$ & 1 & 2 & 3 & 4 & 5 & 6 & 7 & 8 & 9 & 10 \\
\hline
\end{tabular}

The relationship of time and frequency of rainfall is: $T=0,0623 \cdot N^{0,9967}$. The relationship of time and reservoir water fluctuation frequency is: $T=N$, where $T$ is the time in years, $\mathrm{n}$ is the number of water-rock interaction cycle.

Initial mechanical parameters of sandstone obtained by conducting mechanical tests on sandstone from the Three-Gorges Reservoir were used, in which the cohesion is $16,02 \mathrm{MPa}$ and the internal friction angle is $45,61^{\circ}$ [9]. Accessible information shows that in most landslides the earth-rock aggregate has an average value of cohesion of $0,03 \mathrm{MPa}$ and internal friction angle of $22^{\circ}$.

Accordingly, Eq. (1) and Eq. (2) can be converted into Eq. (8):

$N=\mathrm{e}^{\frac{c-c_{0}}{-1,6665}}-1$ or $N=\frac{\ln \frac{\left(\frac{\varphi}{\varphi_{0}}-0,508\right)}{0,492}}{-0,0416}$.

The above equation can help to work out how many wet-dry cycles are needed for complete deterioration of rock into something similar to earth-rock aggregate. $N$ equals 14690 which amounts to 900 years if calculated by cohesion, and that is more than reality because only water is considered for wet and dry cycles, ignoring the role of other factors. And the equation fails if calculated by internal friction angle, for $\left[\left(\varphi / \varphi_{0}\right)-0,508\right]>0$, and $\varphi_{0}=$ $45,61^{\circ}$, that is to say the internal friction angle must be bigger than $23,17^{\circ}$, thus, this model cannot forecast the strength of rock which has suffered great deterioration already.

Similarly, $N$ equals about 356 if calculated by deterioration function corresponding to hydrostatic pressure [8], which means a relatively short time of about 22 years. It is not suitable for the model to simulate the degradation effect of rainfall, but it can simulate the longterm soaking effect of reservoir water, and also can be used for strength prediction of sandstone with different weathered levels.
Theoretically, exposed rock will soften into soil after a certain period of dry-wet cycle. But for the slope with a certain gradient, the infiltration depth of rainfall is limited, and a thicker layer of earth-rock aggregate often exists on the surface, which acts as a protective cover for the rock beneath. When the earth-rock aggregate on the surface moves away in landslide or other forms, the bedrock gets exposed and then the process of degradation starts. Thus, the stability analysis should be focused on the effects of water on hydro-fluctuation belt during the low degradation period of rainfall before landslides occur as soften.

\subsection{Transformations of parameters between rock and rock mass}

Rock is just a part of rock mass, so the mechanical parameters of rock obtained through test should be converted into mechanical parameters of rock mass before applying in engineering analysis. At present, the prevailing method is the rock classification system established by Hoek-Brown et al. who proposed an empirical formula to estimate rock mass parameters such as $\mathrm{m}$ and $\mathrm{s}$ by value of RMR. Hua-Feng Deng has deduced and measured the mechanical parameters of rock mass in Three Gorges Reservoir area from 2006 to 2009 [9] as shown in Tab. 3.

Table 3 Comprehensive determination of mechanical parameters of rock

\begin{tabular}{|c|c|c|c|c|}
\hline \multirow{2}{*}{ Parameters } & \multicolumn{3}{|c|}{ Conjecture value } & $\begin{array}{c}\text { Measured } \\
\text { value }\end{array}$ \\
\cline { 2 - 5 } & 2006 & 2007 & 2008 & 2009 \\
\hline Internal friction angle $/{ }^{\circ}$ & 36,79 & 36,14 & 34,45 & 33,09 \\
\hline Cohesion $/ \mathrm{MPa}$ & 0,36 & 0,35 & 0,34 & 0,32 \\
\hline
\end{tabular}

Since the rock in research area has suffered wet and dry cycles for a long time, the mechanical parameters of rock mass are beyond the mutation, parameters of rock mass in research area should be selected since the first year of impoundment according to the engineering practice. So 2006 was chosen as the starting time to calculate the deterioration of mechanical parameters of rock mass. The converted mechanical parameters of rock mass in hydro-fluctuation belt are showed as Fig. 2.

\section{Long-term stability evaluation of three gorges reservoir bank slope 3.1 Water-rock interaction region in the geological model}

The average width of a landslide is $1200 \mathrm{~m}$, the full length is $1500 \mathrm{~m}$, and the area is 1,8 million square meters. The average thickness is $50 \mathrm{~m}$, the volume is about 90 million cubic meters and the main sliding direction is $20^{\circ}$. The evolution process is featured as gravity anticline damage, and evolving into consequent bedding rock slope. Sliding mass is mainly composed of two parts, the lower layer is disturbed and destructed layered quartz sandstone, and the surface layer is loose accumulational. The middle and rear part of landslide is bedding sliding, sliding zone is constituted by weak coal strata. The front part of sliding is black silty loam clip with a small amount of rock block. Sliding bed mainly consists of the lower strata of Xiangxi. Bedding sliding is 
mainly constituted by Xiangxi carbonaceous silt stones, shear layer consists of quartz sandstone with gravel. On the section, the upper part of landslide bed is the same to the rock formation, in a line and with an inclination of $27^{\circ}$. The cross-sectional view is shown in Fig. 3, the model and material partition are shown in Fig. 4.
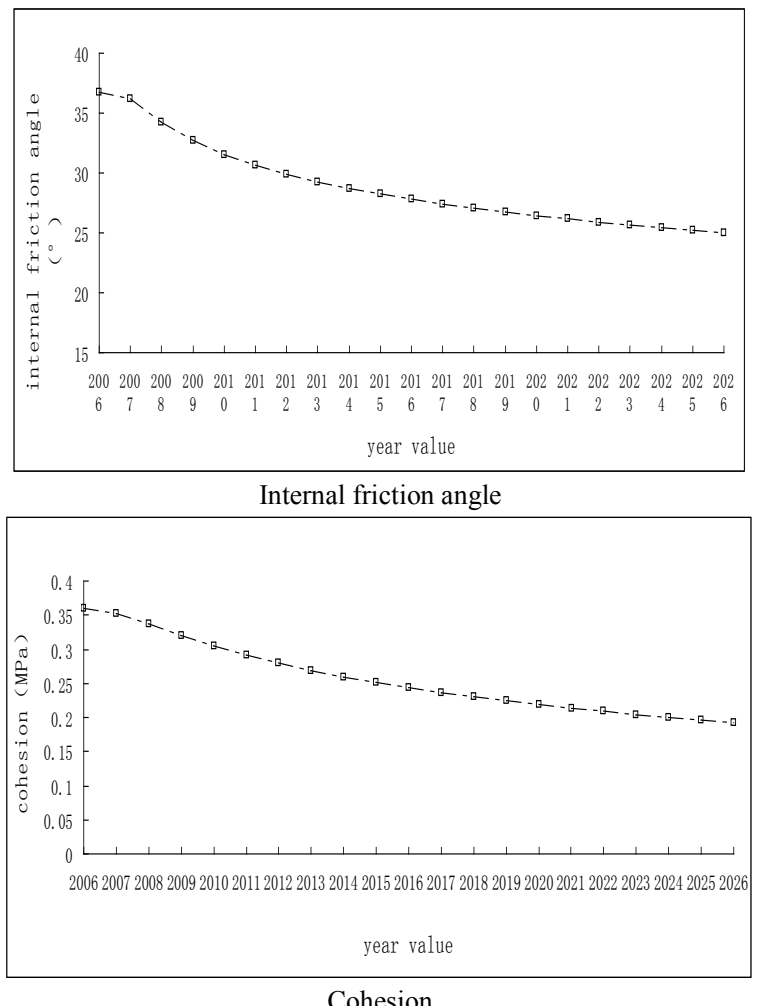

Figure 2 Mechanical parameters of rock mass in variable amplitude band change as time under the water-rock interaction

It can be seen in Fig. 3 that the groundwater change area caused by water level fluctuation is smaller than the dry-wet cycle affected area considered by author. Water pressure is changed with water level, the movement of water in rock causes the deterioration of rock. So, the degrading regulation of rock can be used to approximately describe the degrading regulation of dry-wet cycle zone, which would magnify the impact of dry-wet cycle on slope, and the results predicted will be conservative. Marl layer under water is separated into two parts. The upper part is close to the wet-dry cycle region while the lower part is close to the bedrock. The area of weathered layer, sandstone layer, mudstone layer and dry-wet cycle zone is $19333 \mathrm{~m}^{2}, 66933 \mathrm{~m}^{2}, 60645 \mathrm{~m}^{2}$, and $10737 \mathrm{~m}^{2}$ respectively.

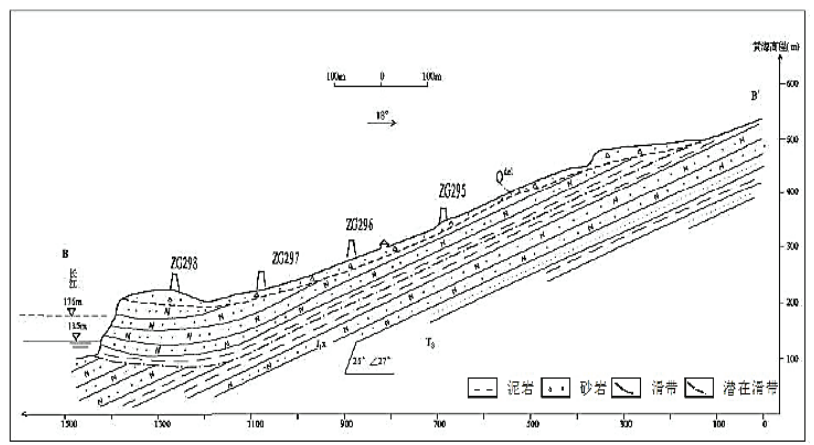

Figure 3 Landslide geological profile
Hydro-fluctuation belt will be affected by rainfall at low water level, but the depth affected is limited due to the presence of the drainage system and the sharp appearance of wading surface. For simplification, the effect of the rainfall is ignored. The water level in Three Gorges Reservoir area ranges from $145 \mathrm{~m}$ to $175 \mathrm{~m}$ as shown in Tab. 1 by GEO-SLOPE software.

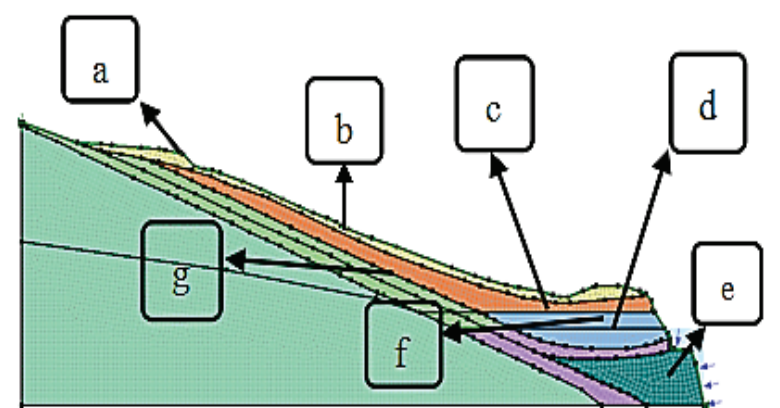

Figure 4 The mechanics model: a) Weathering layer; b) Sand layer; c) 175 m water saturation line; d) 145 m water saturation line; e) Dynamic water soak zone; f) Hydro-fluctuation belt; g) Mudstone layer and the specified sliding zone.

\subsection{Deduction of typical slope stability and failure modes over time}

The stability of typical landslide profile in water level of $145 \mathrm{~m}$ and $175 \mathrm{~m}$ was calculated by GEO-SLOPE software considering degradation effect of water-rock interaction on hydro-fluctuation belt, as shown in Fig. 5.

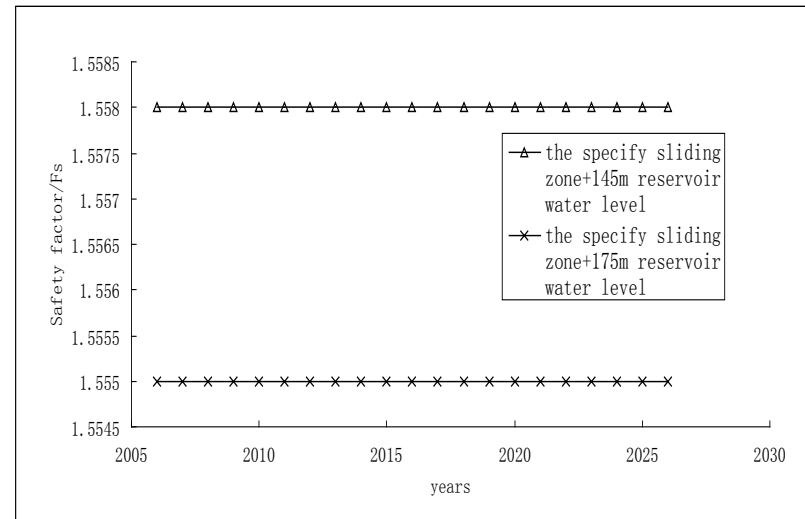

(a)

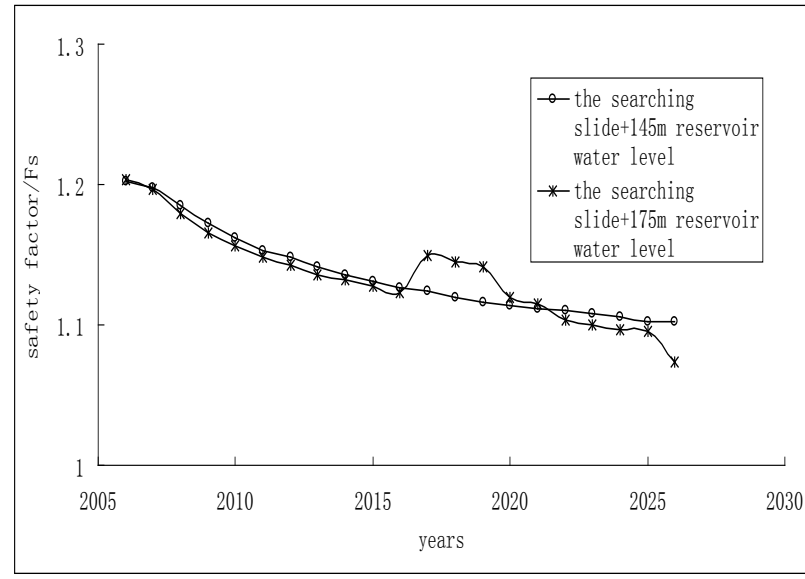

(b)

Figure 5 Stability and time diagram of a typical landslide profile of Three Gorges Reservoir at $145 \mathrm{~m}$ and $175 \mathrm{~m}$ water levels. (a) The relationship of safety factor of the Specify sliding zone and time; (b) The relationship of safety factor of the searching sliding zone and time 
It is shown in Fig. 5 that the deterioration of hydrofluctuation belt has little impact on the safety factor of specified slide, and the changes of safety factor in searching slide show that the effect of hydro-fluctuation belt on landslide stability is obvious. At $145 \mathrm{~m}$ water level, the stability of landslide decreases progressively over time with the decrease rate of reduction; At $175 \mathrm{~m}$ water level, the stability of landslide is almost the same as at $145 \mathrm{~m}$ water level on the whole, but the stability will increase suddenly in 2017 and then decrease gently in the following three years, while in 2020 , it will have a sharp decrease and then decrease progressively year by year. It is considered that the landslide failure mode changes qualitatively during the mutation process. Apart from year 2017 to 2022 , the landslide stability at $175 \mathrm{~m}$ water level is worse than that at $145 \mathrm{~m}$ water lever, showing that the high-level water storage is detrimental to the stability of the landslide, just in accord with the actual situation of bank slope in Three Gorges Reservoir.

Hydro-fluctuation belt degrades progressively under water-rock interaction at $145 \mathrm{~m}$ water level. A new damaging mode of landslide will come up if the antisliding ability in hydro-fluctuation belt is lower than that in specified sliding band, as is shown in Fig. 6.

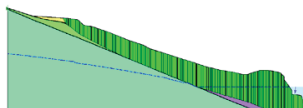

In $2006\left(F_{\mathrm{s}}=1,2\right)$

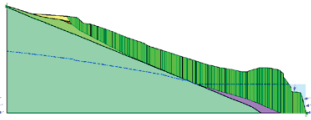

In $2016\left(F_{\mathrm{s}}=1,127\right)$
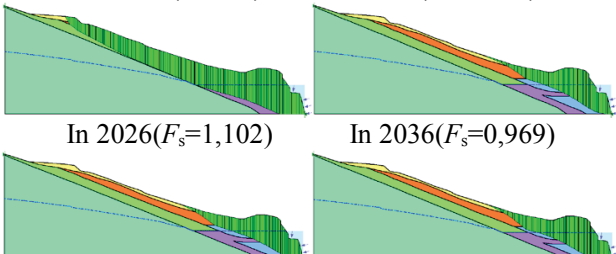

In $2036\left(F_{\mathrm{s}}=0,969\right)$

In $2046\left(F_{\mathrm{s}}=0,953\right) \quad$ When the hydro-fluctuation belt changes into mud $\left(F_{\mathrm{s}}=0,622\right)$

Figure 6 Typical landslide failure mode evolution process at $145 \mathrm{~m}$ water level

At $145 \mathrm{~m}$ water level, the landslide has the risks of slip along with the interface between shale and bedrock. As time passes, hydro-fluctuation belt degrades progressively under water-rock interaction. The destruction path will change due to the rise in the front edge of slip plane if the strength of hydro-fluctuation belt deteriorates: the slide plane will move to the surface of landslide, the shear opening will move to hydrofluctuation belt. When the hydro-fluctuation belt changes into mud that is, becomes too weak to resist the load of the upper rock, the hydro-fluctuation belt will be destroyed at first leading the upper rock to sliding and collapsing along the specified sliding band $[10,11]$.

At $175 \mathrm{~m}$ water level as shown in Fig. 7, the evolution of failure mode of the landslide is highly similar with that at $145 \mathrm{~m}$ water level. The safety factor in Fig. 4(b) will be smaller than practical field due to the restraint function on deformation and further weakening effect on hydro-fluctuation belt from reservoir water pressure. In 2017, the safety factor will suddenly increase for the weakening of hydro-fluctuation belt leading changes in the failure mode of landslide [12]. The slip plane will be almost parallel to the lower branch of shale in 2026, different from that at $145 \mathrm{~m}$ water level.

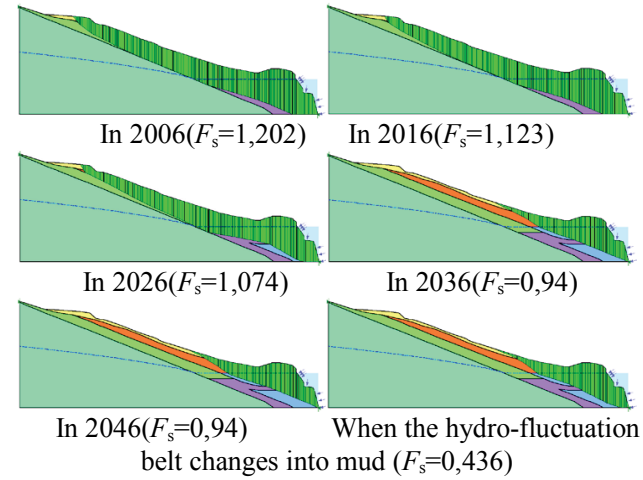

Figure 7 Typical landslide failure mode evolution process at $175 \mathrm{~m}$ water level

\section{Analysis of typical landslide \\ 4.1 Rock parameters sensitivity determination}

Take safety factor $F_{\mathrm{s}}$ as a system feature for it is main indicator of slope stability in slope stability analysis system. Setting a system with characteristic as $F_{\mathrm{s}}=f\left(x_{1}\right.$, $\left.x_{2}, \ldots, x_{n}\right)\left(x_{i}\right.$ is parameters), giving a reference state $x^{*}=\left(x_{1}^{*}, x_{2}^{*}, \ldots, x_{n}^{*}\right)$, the parameters can be changed in a possible extent, analysing the influence of parameters to $F_{\mathrm{s}}$. System features are different in different unit systems. Dimensionless parameters are needed to compare the impact of various parameters on system performance, drawing $\Delta F_{\mathrm{s}} / F_{\mathrm{s}}^{*} \approx \Delta x / x^{*}(i=1,2, \ldots, n)$ curves. The absolute value of curve slope is defined as sensitivity coefficient to reflect the influence of various parameters on system performance. The sensitivity of $i$ influence factor $S_{i}$ can be expressed as Eq. (9):

$S_{i}=\frac{\left|\Delta F_{\mathrm{s}} / F_{\mathrm{s}}\right|}{\left|\Delta x_{i} / x_{i}\right|}$.

where $\left|\Delta F_{\mathrm{s}} / F_{\mathrm{s}}\right|$ is relative change rate of stability safety factor, $\left|\Delta x_{i} / x_{i}\right|$ is relative change rate of factor $x_{i}$. If the value $S_{i}$ is greater, the value of $F_{\mathrm{s}}$ is more sensitive to $x_{i}$ in this condition.

Take weathered layer as an example, the designed cohesions are $x^{*}=\left(\begin{array}{llllll}1 & 20 & 40 & 60 & 80 & 100\end{array}\right)$, the system characteristics are $F_{\mathrm{s}}^{*}=\left(\begin{array}{lllll}0,5 & 1,011 & 1,202 & 1,203 & 1,203\end{array}\right.$ $1,204)$, and the unit of cohesion is $\mathrm{kPa}$.

The designed internal friction angles are $x^{*}=$ $(6,414,834,357,674,683,2)$, the system characteristics are $F_{\mathrm{s}}^{*}=(0,7170,8711,2031,2041,2041,205)$, the unit of the internal friction angle is degree $\left({ }^{\circ}\right)$.

The designed gravities are $x^{*}=$ $(11,8215,7419,6623,5827,5)$, the system characteristics are $F_{\mathrm{s}}^{*}=\left(\begin{array}{lllll}1,22 & 1,221 & 1,202 & 1,194 & 1,028\end{array}\right)$, the unit of density is $\mathrm{N} / \mathrm{cm}^{3}$.

Mechanical parameters sensitivity of different rock stratums were obtained by Eq. (10) as shown in Tab. 4:

Mechanical parameters' sensitivity analysis is not conducted in bedrock in Tab. 4, because it is 
strengthened, less affected by external, and has little effect on slope stability in practice. The sensitivity of deformation modulus is also not analysed either because some related researches [13] show that deformation modulus is not sensitive to the safety factor.

Table 4 Mechanical parameters sensitivity in different rock stratums

\begin{tabular}{|l|c|c|c|}
\hline \multicolumn{1}{|c|}{ Layer $(i)$} & $\begin{array}{c}\text { Sensitivity } \\
\text { of cohesion } \\
c\end{array}$ & $\begin{array}{c}\text { Sensitivity of } \\
\text { internal } \\
\text { friction angle } \\
\varphi\end{array}$ & $\begin{array}{c}\text { Sensitivity of } \\
\text { density } \\
\gamma\end{array}$ \\
\hline Weathering layer(1) & 0,0384 & 0,3111 & 0,0214 \\
\hline Sand layer(2) & 0,0001 & 0,0001 & 0,0403 \\
\hline Mudstone layer(3) & 0.0081 & 0,2420 & 0,0528 \\
\hline $\begin{array}{l}\text { Dry-wet cycle } \\
\text { area(4) }\end{array}$ & 0,0003 & 0,0589 & 0,1028 \\
\hline
\end{tabular}

\subsection{Deterioration rule of comprehensive mechanical parameters}

The comprehensive parameters of rock mass can represent the whole strength of the calculated region. As most of the landslides occurred in upper rock structures, then upper rock structures are taken as research objects. The calculation steps of rock mass comprehensive parameters $[14,15]$ :

(1) Ascertaining importance degree of each parameter in different stratum, namely the weight $q$ of each parameter;
(2) Actual membership degree of rock parameters in different stratum, namely the area ratio $A$ of different stratum;

(3) Ascertaining positive impact of each parameter in different stratum on slope stability, namely the effective weight $Q$;

(4) Weight the mechanical parameters membership degree of rock mass effectively as Eq. (10):

$$
Q_{i}=A_{i} q_{i}, C_{z}=\sum_{i=1}^{4} C_{0 i} Q_{i}^{\prime}, \varphi_{z}=\sum_{i=1}^{4} \varphi_{0 i} Q_{i}^{\prime}, \gamma_{z}=\sum_{i=1}^{4} \gamma_{0 i} Q_{i}^{\prime}
$$

In the equation, $i$ is the number of rock stratum that is $1,2,3$ and 4 in this paper. $C_{z}$ is comprehensive cohesive force value, $\varphi_{z}$ is comprehensive internal friction angle valve and $\gamma_{z}$ is comprehensive unit weight value.

Where, $Q_{i}^{\prime}$ is a homogenization value from $Q_{i}$, $c_{04}=0,36 \cdot\left[1-0,1149 \cdot \ln \left(1+0,2070 \cdot N^{1,8771}\right)\right]$, $\varphi_{04}=36,79 \cdot\left[1-0,0337 \cdot \ln \left(1+0,6836 \cdot N^{3,3055}\right)\right]$, $\gamma_{04}$ is considered invariable with no special studies on it, $i$ is number of rock layer valued 1, 2, 3, 4 .

Using comprehensive rock strength values in 2006 as an example, the calculation results are shown in Tab. 5 .

Table 5 Comprehensive rock strength values in 2006

\begin{tabular}{|c|c|c|c|c|c|c|c|c|c|c|}
\hline \multirow[b]{2}{*}{ Layer $(i)$} & \multirow{2}{*}{$\begin{array}{c}\text { Area } \\
\text { ratio }(A)\end{array}$} & \multicolumn{3}{|c|}{ Cohesion $c(\mathrm{MPa})$} & \multicolumn{3}{|c|}{ Internal friction angle $\varphi\left(^{\circ}\right)$} & \multicolumn{3}{|c|}{ Density $\gamma\left(\mathrm{N} / \mathrm{cm}^{3}\right)$} \\
\hline & & $\begin{array}{l}\text { The initial } \\
\text { value }\left(c_{0}\right)\end{array}$ & Sensitivity & $\begin{array}{c}\text { Rock } \\
\text { weight }(q)\end{array}$ & $\begin{array}{l}\text { The initial } \\
\text { value }\left(\varphi_{0}\right)\end{array}$ & Sensitivity & $\begin{array}{c}\text { Rock } \\
\text { weight }(q)\end{array}$ & $\begin{array}{l}\text { The initial } \\
\text { value }\left(\gamma_{0}\right)\end{array}$ & Sensitivity & $\begin{array}{c}\text { Rock } \\
\text { weight }(q)\end{array}$ \\
\hline $\begin{array}{l}\text { Weathering layer } \\
\text { (1) }\end{array}$ & 0,123 & 0,0300 & 0,0384 & 0,82 & 22 & 0,3111 & 0,51 & 19,66 & 0,0214 & 0,10 \\
\hline Sand layer (2) & 0,424 & 0,2700 & 0,0001 & 0 & 33 & 0,0001 & 0 & 26,16 & 0,0403 & 0,19 \\
\hline Mudstone layer (3) & 0,385 & 0,0405 & 0,0081 & 0,17 & 21,50 & 0,2420 & 0,39 & 28 & 0,0528 & 0,24 \\
\hline $\begin{array}{c}\text { Dry-wet cycled } \\
\text { area (4) }\end{array}$ & 0,068 & 0,3600 & 0,0003 & 0,01 & 36,79 & 0,0589 & 0,1 & 28,78 & 0,1028 & 0,47 \\
\hline \multicolumn{2}{|c|}{ Comprehensive value } & \multicolumn{3}{|c|}{0,036} & \multicolumn{3}{|c|}{22,1} & \multicolumn{3}{|c|}{26,96} \\
\hline
\end{tabular}

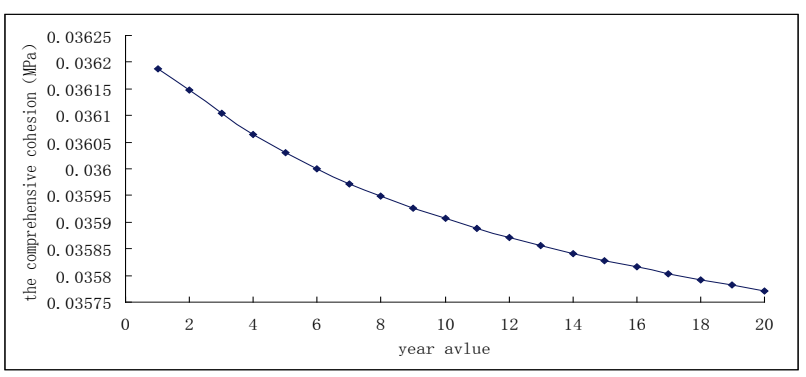

(a)The comprehensive cohesion deterioration curve

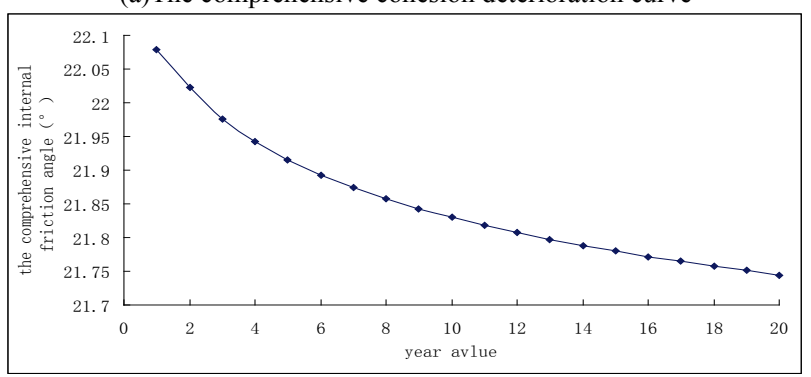

(b)The comprehensive internal friction angle deterioration curve

Figure 8 Deterioration rule of comprehensive strength parameter of the landslide

Fig. 8 is an integrated intensity of rock in 20 years since 2006 , the fourth year is an inflection point, and the degradation rate of the early four years is faster than the following years. The data was fitted as Eq. (11):

$c^{\prime}=2 E-0,7 \cdot N^{2}-2 \cdot E-0,5 \cdot N+c$,

$\varphi^{\prime}=0,0001 \cdot N^{2}-0,0122 \cdot N+\varphi$.

where $c^{\prime}$ is the value of deteriorated cohesion, the initial cohesion $c$ is 0,$036 ; \varphi^{\prime}$ is the value of deteriorated internal friction angle, the initial internal friction angle $\varphi$ is 22,1 ; $N$ is the number of years, ranging from $1,2, \ldots 20$.

The comprehensive strength parameter indicates the capacity of landslide to resist natural calamities. Fig.6 and Fig.7 show the potential slippage mode which is combined with safety factor that can be used in judging whether the landslide mass is safe or not.

\section{Suggestions}

There has been a certain amount of achievements about water-rock interaction with hydro-fluctuation belt bank slope in Three Gorges Reservoir Area, so comparative analysis was taken to get the degradation rule of rock, and the transformed degradation rule was applied 
to rock mass to calculate the change of stability and failure mode of landslide over time.

According to the result, the shear opening of sliding zone moves upward, the glide plane moves to the landslide surface, the tension crack in posterior moves downward, and the range of sliding body gets smaller if the rock mass is degraded to a certain degree. As the hydro-fluctuation belt changes into mud, that is, becomes too weak to resist the load of the upper rock, the hydrofluctuation belt will be destroyed at first leading to the tension fracture in posterior. A large amount of slip mass will collapse along the specified sliding band.

\section{Results and conclusions}

The landslide stability at $145 \mathrm{~m}$ water level is better than that at $175 \mathrm{~m}$ water lever, showing that the degradation effect of water soak on rock is obvious. The safety factor of landslide from 2006 to 2014 conforms to the results of relevant research and the actual situation of the landslides.

The sensitivity of the parameters is studied to consider their contribution to landslide stability in different strata, and then evaluate a comprehensive parameter that can represent the comprehensive intensity of landslide. The comprehensive parameter can be calculated combined with the continuous deterioration of hydro-fluctuation and can reflect the comprehensive disaster resistant capacity of landslide.

It should be pointed out that the dry-wet cycle area studied is bigger than the actual area, the pressure difference causes moisture movement in rock mass, and leads to rock mass degradation. Due to the absence of specialized research, the water-rock coupled deterioration law is adopted to approximately simulate the deterioration law of rock mass underwater. Therefore the results are conservative. It is just a reference for actual project, and cannot guide a project absolutely, the research methods provide a new way to warn and forecast landslide.

\section{Acknowledgments}

This research is supported by the national natural science fund project (51309141), the national natural science fund project (51479102) and public welfare industry special funds of ministry of water resources for scientific research projects (201401029).

\section{References}

[1] De-zhen, G. U.; Si-Jing, Wang. On the interaction between the engineering construction and geologic environment in the man-made lake area. // Proceedings of IV Congress of International Association of Engineering Geology. New Delhi, VII, 1982, pp. 57-64.

[2] Si-jing, Wang. Fundamental problems of environmental engineering geology in mountainous areas-a general view. Proceedings. // International Symposium on Engineering Geological Environment in Mountainous Areas. 2(1987), pp. 381-393.

[3] Li, Kegang; Zheng, Dongpu; Huang, Weihui. Mechanical behaviour of sandstone and its neural network simulation of constitutive model considering cyclic drying-wetting effect.
// Rock and Soil Mechanics. 34, S2(2013), pp. 168-173 (in Chinese).

[4] Lin, M. L.; Jeng, F. S.; Tsai, L. S. et al. Wetting weaking of tertiary sandstones-mechanism. // Environ Geological. 48, (2005), pp. 265-275. DOI: 10.1007/s00254-005-1318-y

[5] Zhang, Ming; Hu, Ruilin; Cui, Fangpeng et al. Stability study on reservoir accumulation body considering physical and chemical reactions between water and accumulation body-taking XiaZanRi accumulation body for example. // Chinese Journal of Rock Mechanics and Engineering. 27, S2(2008), pp. 3701-3704.

[6] Liu, Xin-rong; Fu, Yan; Wang, Rong-xing. Stability of reservoir bank slope under water-rock interaction. // Rock and Soil Mechanics. 30, 3(2009), pp. 613-616.

[7] Liu, Xin-rong; Fu, Yan; Wang, Rong-xing. Deterioration rules of shear strength of sand rock under water-rock interaction of reservoir. // Chinese Journal of Geotechnical Engineering. 30, 9(2008), pp. 1298-1302.

[8] Fu, Yan; Liu, Xin-rong; Zhang, Rong-xing. Study on the influence of water -rock interaction to the strength of sandstone. // Hydrogeology \& Engineering Geology. 36, 6(2009), pp. 54-58.

[9] Deng, Hua-feng. Study on the Mechanism and Effects of Water-Rock Interaction under Water Level Change Region. Wuhan University, (2010) Ph.D.

[10] Massey, C.; Petley, D.; McSaveney, M. Patterns of movement in reactivated the bank slopes. // EngGeol. 159(2013), pp. 1-19. DOI: 10.1016/j.enggeo.2013.03.011

[11] Strozzi, T.; Farina, P.; Crosini, A.; Ambrosi, C.; Thüring, A.; Zilger, J.; Wiesmann, A.; Wegmüller, U.; Werner, C. Survey and monitoring of the bank slope displacements by means of L-band satellite SAR interferometry. // The Bank Slopes. 2(2005), pp. 193-201.

[12] Terlien, M. The determination of statistical and deterministic hydrological the bank slope-triggering thresholds. // Environ Geol. 35, 2-3(1998), pp. 124-130.

[13] Wan, Liang-peng. Layered sensitivity analysis and weight determination of rock slope stability impacting factors. // Water Resources and Hydropower Engineering. 43, 3(2012), pp. 59-63.

[14] Mehdi, Ebrat; Reza, Ghodsi. Construction Project Risk Assessment by using Adaptive-Network-based Fuzzy Inference System: An Empirical Study. // KSCE Journal of Civil Engineering. 18, 5(2014), pp. 1213-1227. DOl: 10.1007/s12205-014-0139-5

[15] Jun, Song; Fu-Yan, Chen. Calculation model for thermomechanical coupling and 3D numerical simulation for concrete tower of cable-stayed bridge. // Environmental and Earth Sciences Research Journal. 2, 1(2015), pp. 13-16. DOI: 10.18280/EESRJ.020103

\section{Authors' addresses}

Liang-Peng Wan

School of Water Resources and Hydropower Engineering, Wuhan University,

Bayi road No. 299, Wuchang district in Wuhan of Hubei, China E-mail: 364528061@qq.com

\section{Mei-Ling Zhou}

China Three Gorges University,

Daxue road No. 8, Xiling district in Yichang of Hubei, China E-mail: 535609831@qq.com

\section{Subin Desar}

China Three Gorges University, Daxue road No. 8, Xiling district in Yichang of Hubei, China E-mail: subindesar@yahoo.com 